\title{
Gender Pay Gap Among Urban-Urban Migrant Workers: Pakistan's Two-Tier Urban Labor Market
}

\author{
Muhammad Umair \\ \& \\ Lubna Naz \\ Department of Economics \\ University of Karachi
}

\begin{abstract}
Urban-urban migration has socio-economic and demographic consequences on the labor markets. It affects job mobility and gender-balance in the urban workplace. This study analyzes the gender wage gap among urban-urban migrant workers in Pakistan. The study used the most recent Labour Force Survey, a nationally representative dataset, to identify the determinants of wages for male and female migrant workers separately. The wages of urban-urban female migrants tend to be $45 \%$ lower than their male counterparts. The results indicate disparities in working hours and human capital endowment as some of the contributing factors to the increasing gender wage gap. This research calls for implementing drastic measures, i.e., gender-insensitive capacity building of urban migrant workers, workplace incentives for women, and enhancement of women leadership roles, to reduce gender inequalities in the urban labor market.
\end{abstract}

Keywords: Urban-Urban Migration, Gender Wage Gap, Working Hours, Human Capital Investment.

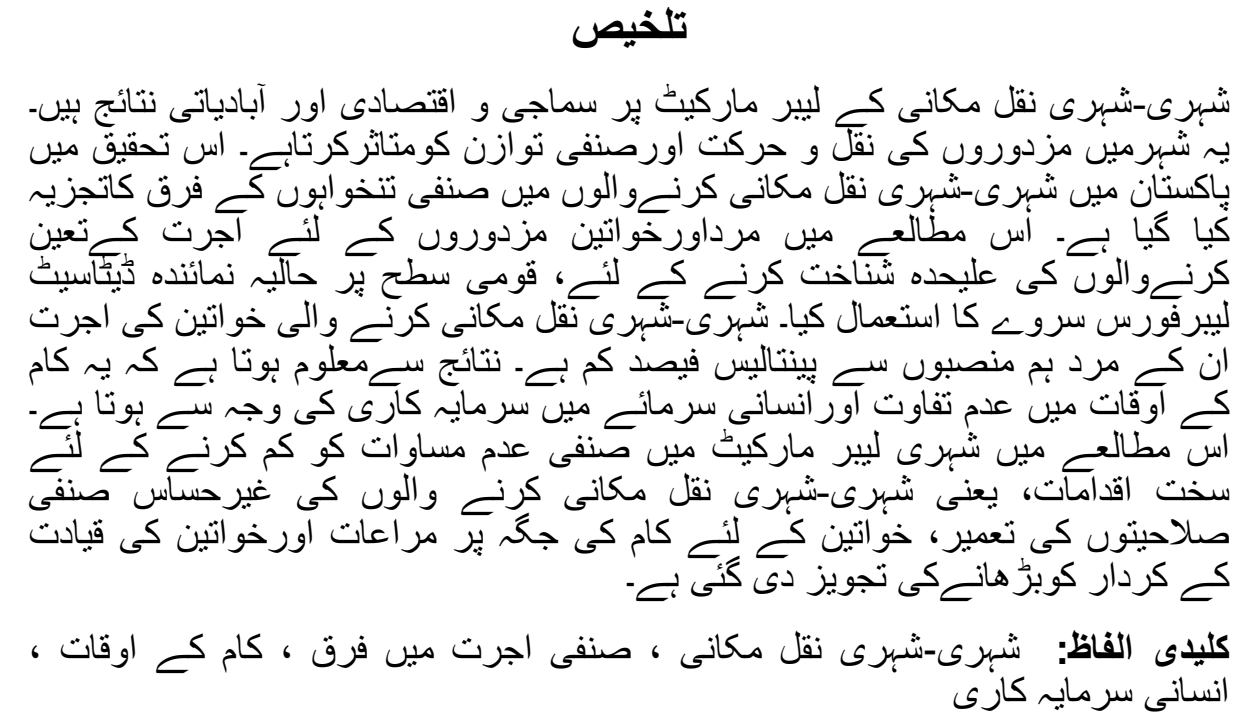

This work is Licensed under a Creative Commons Attribution-NonCommercial 4.0 International License (c) (i) () 


\section{Introduction}

Urban-urban migration is the movement of people from one urban area to another. It increases economic opportunities and improves the endowments of the population. The mobility, income, and employment rates of urban-urban migrants are likely to be higher than their rural-urban counterparts (Peek \& Antolinez, 1977). The internal migration of labor affects labor supply and wages in the urban labor market (Pérez-Campuzano, et al., 2018). The urban migrants earn higher due to differences in human capital development and working hours differentials (like India, see Hnatkovska \& Lahiri, 2015).

The rural-urban migration is considered as the most important spatial form of internal migration (De Haas, 2010). Besides, the urban-urban migration is a significant dimension of internal migration in both the developed and developing economies. Migration between urban centers is under-researched in literature. The urban-urban migration is common in Latin American countries since the 1980s. The most populous economies of the developing countries (like China and others) have also seen increased urban-urban migration in the past two decades (Zhang, Wang, Harris \& Leckie, 2020).

Around $37 \%$ of the total population of Pakistan is living in urban areas. One-third of the population is comprised of the labor force (WDI, 2019). However, the gender wage gap is persistent among urban-urban migrants. The gender pay gap is an international issue focused on Sustainable Development Goals ${ }^{1}$. It is due to endowment (productivity-related differences) and discrimination (different returns to covariates) effects (Magnani \& Zhu, 2012; Agesa \& Agesa, 1999; Haughton \& Sun, 2018). The proportion of the urban-urban migrant workers in Pakistan is around a quarter in the migrant labor force. Besides male, female workers in Pakistan also migrate from one urban area to another. The literacy rates in the urban migrant workers are higher than the other migratory streams. Most of the migrant workers are skilled and are employed in industrial and services sectors (LFS, 2017-18).

Rural-rural migration is common in undeveloped societies with lower urbanization, while urban-urban migration is significant in developed economies with higher urbanization and development (Lucas, 2016). Urban-urban migrant workers are a significant proportion of the urban labor markets (Baines, 2005).The gender wage gap among urbanurban migrants was higher than the gender wage gap in the labor markets of Pakistan. The average monthly wages of females $(11,884$ PKR) in Pakistan were $40 \%$ lower than their males $(19,943$ PKR) counterparts, while the wage gap was $45 \%$ among the urbanurban migrants. The urban-urban male migrants earned 30,843 PKR, while female migrants earned 17,095 PKR (LFS, 2017-18).

Female migrants actively participate in the economic activities of Pakistan (Dale, Fieldhouse, Shaheen \& Kalra, 2002). The proportion of the urban-urban female migrant workers was $22 \%$ in 2017-18, the second-highest after rural-rural migrant female 
participation (44\%), among the migrant female labor force participation. Migration has multidimensional and profound effects on the labor market outcomes. The gender wage gap is due to disparities in the socio-economic and demographic characteristics among male and female urban-urban migrant workers.

Different studies in Pakistan estimated the gender wage gap in Pakistan. Most of the previous studies, like Ashraf \& Ashraf (1993a) and Ashraf \& Ashraf (1993b), used household dataset, which was meant to provide information on household-expenditures and socio-demographic characteristics, and lack information to explore the determinants of gender wage gap across sectors and for various groups. This study aims to examine the gender-based differences in the socio-economic and demographic characteristics of the urban-urban migrant workers in Pakistan. The study used the nationally representative Labour force data set (LFS, 2017-18). Ordinary Least Squares (OLS) regression was used to identify the determinants of wages for male and female migrant workers separately.

To the best of our knowledge, none of the earlier studies, so far, has undertaken a detailed analysis of the gender pay gap among urban-urban migrant workers in Pakistan. Most of the previous research focused on the rural-urban gender pay gap. The present study hypothesized that (i) male urban-urban migrants earn higher wages than their female counterparts and (ii) the gender wage gap in urban market arises due to gendered differences in the socioeconomic and demographic characteristics among urban-urban migrants.

\section{Characteristics of Urban-Urban Migrant Workers in Pakistan}

The wage gap significantly depends on the demographic characteristics of urban-urban migrant workers. Age is an important determinant of human capital accumulation. It can be used as a proxy variable for experience (Lim, et al., 2010; Mitchell, et al., 2000). Female migrants were relatively younger than their male counterparts (Table 1). The mean age of male migrants was 37.9 years, while that of their female counterparts was 34.4 years. The marital status shows that around three-fourth of the migrants got married (74.3\% males and $64.6 \%$ females). The proportion of widowed/divorced female migrants $(8.3 \%)$ was more than their male counterparts $(2.1 \%)$. The education of urban-urban migrant workers was the highest among different migration streams. $81.7 \%$ male and $72.5 \%$ female migrants were educated. Moreover, $19.9 \%$ of male migrants and 21.5 female migrants had graduated. The sectoral classification is based on PSIC (2010) that follows ISIC (2008). It shows that a bit less than two-third of workers were employed in the services sector $(63.6 \%$ males and $63.7 \%$ females). The least proportion of migrants was employed in the agriculture sector. The percentage of female migrants in the agriculture sector was higher than their male counterparts. 
The occupational classification is based on PSCO (2015) that follows ISCO (2008). The occupational classification shows that around 19\% of the male migrants were managers or professionals. Most of the male migrant workers were craft/trade workers (21.9\%), services and sales workers (17.7), or plant/machine operators (12.4\%). In contrast, most of the female migrant workers were professionals $(42.2 \%)$, craft/trade workers $(19.8 \%)$, or working in elementary occupations $(22.3 \%)$.

Table: 1

Socio-economic and demographic characteristics of urban-urban migrant workers in Pakistan

\begin{tabular}{|c|c|c|c|c|c|}
\hline \multirow[b]{2}{*}{ Characteristics } & \multicolumn{2}{|c|}{ Gender } & \multicolumn{3}{|c|}{$\begin{array}{c}\text { Income } \\
\text { (thousand PKR) }\end{array}$} \\
\hline & Male & Female & Male & Female & $\begin{array}{c}\text { Gender wage } \\
\text { gap }^{2} \\
\text { (percent) }\end{array}$ \\
\hline Age (years) & 37.9 & 34.4 & 30.8 & 17.1 & 45 \\
\hline \multicolumn{6}{|l|}{ Marital status (percent) } \\
\hline Never-married & 23.6 & 27.1 & 23.1 & 18.1 & 22 \\
\hline Married & 74.3 & 64.6 & 33.6 & 18.3 & 46 \\
\hline Widowed/Divorced & 2.1 & 8.3 & 19.6 & 4.9 & 75 \\
\hline \multicolumn{6}{|l|}{ Education (percent) } \\
\hline No education & 18.3 & 27.5 & 21.5 & 6.2 & 71 \\
\hline Primary & 15.6 & 15.5 & 16.1 & 6.9 & 57 \\
\hline Matric & 34.2 & 27.4 & 21.7 & 10.3 & 53 \\
\hline Intermediate & 12.0 & 8.1 & 25.7 & 17.4 & 32 \\
\hline Graduation and above & 19.9 & 21.5 & 53.0 & 31.1 & 41 \\
\hline \multicolumn{6}{|l|}{ Sector (percent) } \\
\hline Agriculture & 0.8 & 2.2 & 11.7 & 2.6 & 78 \\
\hline Industry & 35.6 & 34.1 & 25.0 & 7.2 & 71 \\
\hline Services & 63.6 & 63.7 & 35.3 & 20.7 & 41 \\
\hline \multicolumn{6}{|l|}{ Occupation (percent) } \\
\hline Managers & 7.8 & 4.9 & 72.4 & 41.3 & 43 \\
\hline Professionals & 11.4 & 42.2 & 60.3 & 24.0 & 60 \\
\hline Technicians & 13.1 & 5.6 & 35.6 & 27.4 & 23 \\
\hline Clerical support & 5.9 & 2.0 & 33.2 & 21.0 & 37 \\
\hline Service/sales workers & 17.7 & 2.1 & 19.2 & 6.1 & 68 \\
\hline Skilled agricultural workers & 0.0 & - & 6.0 & - & - \\
\hline Craft/trade workers & 21.9 & 19.8 & 18.5 & 5.7 & 69 \\
\hline Plant/machine operators & 12.4 & 1.1 & 19.0 & 5.4 & 72 \\
\hline Elementary occupations & 9.8 & 22.3 & 19.6 & 7.5 & 62 \\
\hline
\end{tabular}

Source: Authors' tabulation from LFS (2017-18) 
Female urban-urban migrants earned $45 \%$ lower than their male counterparts. Married males and females earned higher wages among different groups of marital status. However, the ratio was the lowest among the never-married migrant workers. The comparison of educational attainment shows that female workers with no education earned $22 \%$ lower than their male counterparts. The difference declined at higher education levels. On average, the earnings of workers were the highest in the services sectors. However, the gender wage ratio of average monthly wages was the lowest in the services sector. The gender wage gap in the sector was $41 \%$. The classification of employment by occupation shows that managers earned the highest income. The gender wage gap was the highest among plant/machine operators (72\%) and craft/related trade workers (69\%), while the lowest among technicians (23\%) and clerical support workers (37\%). The gender wage gap among managers and professionals was $43 \%$ and $60 \%$, respectively.

\section{Review of Literature}

There are substantial differences in the earnings of workers based on education differentials (Schultz, 1961). Becker (1962) initially formalized human capital theory. The theory explains that investment in schooling and getting information increases the productivity of labor. Marital status adversely affects female labor force participation. Human capital investment and family time allocation can increase female labor force participation and earnings (Mincer \& Polachek, 1974). The marital status and family responsibilities create a gender wage gap, even if the human capital is the same.

Females have fewer working hours than their male counterparts due to household activities of married females. Marital status also affects occupational choice (Becker, 1985). Females are occupied in agricultural activities and household responsibilities. Likewise, males carry out market-based jobs. Human capital investment increases economic growth. Besides their male counterparts, female workers partially participate in market-based employment, so they have fewer incentives in a human capital investment such as education and training (Becker, 1993). One of the essential reasons for the gender wage gap is the working hours differential among male and female workers. Household responsibilities contribute significantly to the gender pay gap (Erosa, Fuster \& Restuccia, 2015).

There are limited studies in the literature that focused gender wage gap among migrant workers. Most of the studies determined the gender wage gap among rural-urban migrants in China. The country has the most extensive stock of internal migrants (WDI, 2019; Ma, 2017). Zhu (2016) analyzed gender wage gaps among urban native and 
migrant workers in China. It compared socio-economic characteristics among the two groups. It also examined the wage gap among urban native and migrant workers by gender. On average, the gender wage ratio among migrant workers (19.3\%) was higher than their urban counterparts $(12.7 \%)$ in 2002 . The rate among urban residents increased, while it declined among migrant workers in 2007. The wage gap was attributed to productivity (such as schooling and experience) and discrimination (different returns to covariates) effects. The discrimination effect dominates due to their local registration system and gender inequalities.

Magnani \& Zhu (2012) examined China's representative data set (CHIP-2002) to find a $30 \%$ gender wage gap among rural-urban migrants. The study analyzed the normalized difference between the socio-economic and demographic characteristics by gender. The classification was compared by eight occupational groups, five employer ownerships, seven industrial groups, and across twelve provinces. It used OLS and unconditional quintile regressions for estimations. The paper found a non-uniform earning difference along with the wage distribution. The study concludes sticky floor effects among urban workers and glass ceiling effects among rural migrants. Both consequences are serious against female workers.

Another study by Lee (2012) used survey data, China Urban Labor Survey (CULS2005), and employed standard wage decomposition methods to decompose gendered based wage gaps among migrant and native workers of five larger cities of China. This research was different from the previous studies as it included all financial and nonfinancial benefits of income. The migrants were younger and had more years of schooling and experience. The study ran wage regressions of migrant and urban workers by gender. The study confirmed the existence of wage differences in the urban labor markets due to differences in the socio-economic and demographic characteristics of urban workers.

Agesa \& Agesa (1999) analyzed the male-female pay gap among rural-urban migrants in Kenya. The study supported the theory of Harris \& Todaro (1970). According to this theory, skilled workers had a high probability of migration. Males were more inclined to urban migration than their female counterparts. The expected wage gap motivated males more for rural-urban migration. The study compared the percentage distribution of the rural and urban population by educational attainment, gender, and age group - the study estimated earning equations for migrants and non-migrants. The significance of the migrants' wage gap was higher for males than their female counterparts. Male earned $23 \%$ higher wages in the urban areas, while $12 \%$ higher wages in the rural areas than their female counterparts. 
The gender earning differential has been studied extensively in Pakistan. Sabir \& Aftab (2007) analyzed the changes in the gender wage gap in Pakistan by employing the mean gender wage gap, wage decomposition analysis, and the gender wage gap along with the wage distribution. The study used three waves of LFS ranging over a decade. The gender wage gap at mean had increased over time, from 50\% in 1996-97 to more than $60 \%$ in 2005-06. However, the wage gap declined at the top end of the wage distribution. The proportion of graduate females was higher than their male counterparts. However, there was a mixed pattern of gender wage gap at different quantiles. The decomposition analysis confirmed that most of the gender wage gap was attributed to gender discrimination.

Siddiqui \& Siddiqui (1998) determined a gender wage gap of $43 \%$ in Pakistan. The study employed Household Income and Expenditure Survey (1993-94) to estimate Mincerian wage equations (included only schooling and age as explanatory variables). The rate of return to education was higher for females, while the returns to age (a proxy variable for experience) were higher for males. The study also estimated extended earning functions for each gender. The study concluded that the earnings of urban workers were higher than their rural counterparts. The occupational choice and industrial distribution significantly determined the wages of each gender. Besides the characteristic differentials, the discrimination effect also attributed to the gender wage gap. Market discrimination could be reduced with human capital development.

Ashraf \& Ashraf (1993a) assessed the male-female wage gap in the Rawalpindi city, Pakistan. The study used survey data that had a small proportion of migrant workers as well. The study employed different models to estimate the earnings gap while used Heckman procedure for sample selection bias. Age, marital status, different levels of education, years of migration, and others were among the explanatory variables in the wage equations. The gender wage gap was attributed more to the discrimination effect than the productivity effect. This discrimination was due to the feudal system and patriarchal societies.

Another study by Ashraf \& Ashraf (1993b) compared the gender wage gap in Pakistan, at the national and provincial levels from 1979 to 1985 . The study used survey data for different levels of education, industrial groups, and others as explanatory variables. The study employed different models to estimate the earnings gap. The gender wage gap reduced from $63 \%$ to $33 \%$ over time. The earning difference was more substantial in rural areas than urban ones. In the province of Baluchistan, the earnings of females were higher than their male counterparts. Other provinces experienced a positive male-female wage gap. All industrial groups experienced a declining wage gap except the agriculture 
sector that did not see any significant change. The study found a broad-based decline across the provinces and industrial groups.

Ahmed \& Hyder (2008) used survey data to estimate OLS and quantile regression for wage gaps in the public and private sectors of Pakistan. The study concluded that educational attainment contributed the most to occupational segregation. The female labor force participation was limited to specific sectors. The female workers are not much disadvantaged at the higher level of wage distribution as experienced in most of the developed economies. The study suggested investments for human capital development that could help in reducing the gender wage gap in Pakistan.

Ahmed \& McGillivray (2015) determine a declining male-female pay gap in Bangladesh. The gap declined by $31 \%$ over 1999-2009. They used three waves of the LFS and compared the summary statistics of workers and their wage differences by gender, based on the socio-economic and demographic characteristics. The wage gap was higher at the lower end than the upper one of the wage distributions. The study used kernel density estimation, Oaxaca-Blinder decomposition, and Wellington decomposition for different years. There was a significant but declining proportion of discrimination effect in the gender wage gap over time. However, the improvement in terms of the declining gender wage gap was more at the lower end due to increased human capital development and decreased gender discrimination in the labor markets.

Ahmed \& Maitra (2010) employed survey data to estimate the gender wage gap among the urban and rural labor markets of Bangladesh. Female workers earned less than half the wages of male workers, both in the urban and rural labor markets. The gender wage gap was $46 \%$ in the urban labor markets. In contrast, it was $44 \%$ in the rural labor markets. The study estimated wage equations separately across gender for urban and rural workers. Most of the wage gaps in the labor markets were attributed to discrimination against female workers. The correction of sample selection bias increased the discrimination effect and the gender wage gap.

The gender wage gap is a common characteristic in the developed countries. Van der Meer (2008) explored the male-female pay gap in the Netherlands. The study used different survey data sets and found a non-declining nineteen percent gender wage gap in the labor markets. The labor markets had become more competitive. The productivity differences between male and female workers had been on a declining trend over time. However, the discrimination effects could not be ignored; male workers were overpaid, while female workers were underpaid. Males were full-time workers, while most of the females were part-time workers. Male workers were committed more to their employers than their female counterparts. Male workers were diverted more towards the financial returns, while the female workers were diverted towards social consents. 
Anspal (2015) found a gender wage gap of 30\% in Estonia, the highest among the European Union. The economy had the highest degree of gender segregation. The study used survey data for the year 2010 and employed a matching based decomposition technique. The proportion of white-collar professional females was more extensive than their male counterparts. Females were more likely to serve as a professional. Females were mostly employed in the education and health sectors with regulated wages. The proportion of females in the public sector was larger than their male counterparts. However, the discrimination effect contributed to half in the gender wage gap. The discrimination effect was lesser for professional females, while the highest for craft/trade workers.

Urban-urban migration is an increasingly important topic for the populous economies of the world. The increased urbanization has also added the subject matters of urban-urban migration in internal migration. It directly or indirectly affects labor market outcomes such as wages, employment opportunities, and spatial distribution. This study is the first attempt to determine the gender wage gap among urban-urban migrants in Pakistan. The earning gaps in the urban market arise due to gendered based differences in the socioeconomic and demographic characteristics.

\section{Data and Methods}

\section{Data}

The study used the recent Labour Force Survey (LFS, 2017-18), a nationally representative data set for the analysis. The total number of wage-earning urban-urban migrant workers was 857; 699 males and 158 females. There are varying socioeconomic and demographic characteristics, such as age, gender, marital status, education, and employment by sector and occupation of urban-urban migrants. Age is a discrete variable that shows the age of a migrant worker in years. Age squared is the square of the total age of a migrant worker. The marital status of migrant workers is classified into three categories; never-married, married and widowed/divorced. The education of a migrant worker is categorized into no education, primary (schooling up to five years), matric (schooling from six to matric), intermediate (higher secondary schooling), and graduation and above (university degree). The employment sector of a migrant worker is grouped into three vital sectors of the economy based on PSIC (2010). The three sectors included agriculture, industry, and services. The employment by the occupation of a migrant worker is sorted into nine major groups based on PSCO (2015). 


\section{Methods}

The study employs OLS to estimate unknown parameters of the wage equations in linear regression models for the urban-urban migrants. Two sets of estimates for male and female migrants, $\beta_{\mathrm{m}}$ and $\beta_{\mathrm{f}}$, respectively, are obtained by regressing the distinct logarithmic wage functions in equations (1) and (2) as:

$$
\begin{array}{rlllll}
\log \mathrm{W}_{\mathrm{m}_{\mathrm{i}}}=\alpha_{\mathrm{m}_{\mathrm{i}}}+\mathrm{X}_{\mathrm{m}_{\mathrm{i}}} \beta_{\mathrm{m}_{\mathrm{i}}}+\varepsilon_{\mathrm{m}_{\mathrm{i}}} & \ldots & \ldots & \ldots & \ldots & \ldots \\
\log \mathrm{W}_{\mathrm{f}_{\mathrm{i}}}=\alpha_{\mathrm{f}_{\mathrm{i}}}+\mathrm{X}_{\mathrm{f}_{\mathrm{i}}} \beta_{\mathrm{f}_{\mathrm{i}}}+\varepsilon_{\mathrm{f}_{\mathrm{i}}} & \ldots & \ldots & \ldots & \ldots & \ldots
\end{array}
$$

Where $\mathrm{W}_{\mathrm{i}}$ is the logarithmic monthly wage of the $\mathrm{i}^{\text {th }}$ urban-urban migrant worker, $\mathrm{W}_{\mathrm{m}_{\mathrm{i}}}$ is the monthly wage of male migrants and $\mathrm{W}_{\mathrm{f}_{\mathrm{i}}}$ is the monthly wage of female migrants. $\mathrm{X}_{\mathrm{m}_{\mathrm{i}}}$ is a vector of explanatory variables for males, while $\mathrm{X}_{\mathrm{f}_{\mathrm{i}}}$ is for females. The explanatory variables include age, marital status, education, sector, and occupation. $\varepsilon$ represents error term.

\section{Results}

Table 2 compares OLS regression estimates of urban-urban migrant workers by gender. There was a positive and significant effect of age on the monthly wages of both male and female migrants. The increase in migrants' age reflects more years of experience. However, the coefficient of age squared was negative for males. The effect on wages lessened as people get older. The comparison of the base category of never-married shows that married males earned 3\% higher wages, while married females earned $38 \%$ higher wages than other corresponding groups. The widowed/divorced migrants earned lower than their never-married counterparts. The wages of literate migrants were higher than their uneducated counterparts. Among males, migrants with matric and intermediate received $8 \%$ and $11 \%$ higher wages than the reference group, respectively. However, female migrants with matric and intermediate had $44 \%$ and $46 \%$ higher wages than the reference group, respectively. The sectoral analysis shows that the wages of both male and female migrants were the highest in the services and industrial sectors. Migrants in the agriculture sector earned the lowest wages. Among the employment by occupation, skilled white-collar workers earned the highest wages, such as managers and professionals. 
Table: 2

OLS regression estimates

\begin{tabular}{|c|c|c|c|c|}
\hline \multirow{2}{*}{ Characteristics } & \multicolumn{2}{|c|}{ Male } & \multicolumn{2}{|c|}{ Female } \\
\hline & Coeff. & SE & Coeff. & SE \\
\hline Constant & $8.7862^{*}$ & 0.6048 & $9.1687^{*}$ & 1.8265 \\
\hline Age & $0.0268^{*}$ & 0.0107 & 0.0433 & 0.0389 \\
\hline Age squared & -0.0002 & 0.0001 & -0.0007 & 0.0005 \\
\hline \multicolumn{5}{|l|}{ Marital status } \\
\hline Never-married & - & - & - & - \\
\hline Married & 0.0332 & 0.0670 & $0.3802 * * *$ & 0.2216 \\
\hline Widowed/Divorced & -0.2171 & 0.1532 & -0.1682 & 0.3173 \\
\hline \multicolumn{5}{|l|}{ Education } \\
\hline No education & - & - & - & - \\
\hline Primary & 0.0889 & 0.0691 & $0.4421 * *$ & 0.2224 \\
\hline Matric & 0.0832 & 0.0584 & $0.4371 * *$ & 0.2125 \\
\hline Intermediate & 0.1124 & 0.0778 & 0.4646 & 0.3646 \\
\hline Graduation & $0.4796^{*}$ & 0.0792 & $1.1308^{*}$ & 0.3156 \\
\hline \multicolumn{5}{|l|}{ Sector } \\
\hline Agriculture & - & - & - & - \\
\hline Industry & 0.7901 & 0.5570 & 0.6060 & 0.8309 \\
\hline Services & 0.8535 & 0.5569 & 0.7430 & 0.7937 \\
\hline \multicolumn{5}{|l|}{ Occupation } \\
\hline Managers & - & - & - & - \\
\hline Professionals & -0.1430 & 0.1144 & -0.7126 & 1.4749 \\
\hline Technicians & $-0.3356^{*}$ & 0.1116 & -0.3105 & 1.4998 \\
\hline Clerical support & $-0.4048 *$ & 0.1263 & 0.3544 & 1.6263 \\
\hline Service/sales workers & $-0.7851 *$ & 0.1160 & -1.2682 & 1.5454 \\
\hline Skilled agricultural workers & -2.1172 & 1.5804 & - & - \\
\hline Craft/trade workers & $-0.7308^{*}$ & 0.1125 & -1.2774 & 1.5265 \\
\hline Plant/machine operators & $-0.6576^{*}$ & 0.1182 & -1.1725 & 1.6144 \\
\hline Elementary occupations & $-0.6736^{*}$ & 0.1221 & -0.9777 & 1.5011 \\
\hline R-squared & \multicolumn{2}{|c|}{0.4601} & \multicolumn{2}{|c|}{0.4118} \\
\hline Number of observations & \multicolumn{2}{|c|}{699} & \multicolumn{2}{|c|}{158} \\
\hline F-statistics & $\mathrm{F}(18,680)$ & $32.19^{*}$ & $\mathrm{~F}(17,140$ & $=5.77^{*}$ \\
\hline \multicolumn{3}{|l|}{ Source: Authors' estimation. } & & \\
\hline
\end{tabular}




\section{Discussion}

Pakistan has experienced speedy urbanization in the South Asian region. The increased urbanization to $37 \%$ in 2018 has increased the importance of urban-urban migration. It also supports the push and pull theory of migration. Individuals move from low-income to high-income urban centers. Besides rural-urban migrants, the urban-urban migrants make up a significant proportion of Pakistan's total internal migration. However, the results confirm the existence of the gender pay gap among urban-urban migrants. The urban-urban migrant workers have diversified socio-economic and demographic characteristics than other migration streams. Female workers are younger than their male counterparts. There is a positive effect of age on migrants' income, as higher age shows higher human capital accumulation. There is a diminished effect of age squared on wages. The productivity analysis shows that older migrants have lesser productivity that returns them lower income. Married migrants have more working hours to earn higher wages to satisfy their household's needs.

The educational level of urban-urban migrants is higher than return them higher wages than other migratory flows. They are mostly employed in formal sectors (Peek \& Antolinez, 1977; Lee, 2012). Both male and female literate migrants earn higher wages than their uneducated counterparts at different levels along with the wage distribution. However, the returns are more for females as the literacy rates are lower among female workers. Therefore, females are employed mainly in low skilled jobs (Schultz, 1961). Most of the urban-urban migrants are employed in the industrial and services sector, as these sectors hire educated and skilled labor, and pay them higher returns. The sectoral classification shows that the services and industrial sectors mostly employed male workers. At the same time, females remain restricted to low-profile industries in the services sector, which also widens the gender pay gap. Indeed, some of the part-time female migrants are earning lower than the minimum monthly wages due to their fewer working hours and lower productivity.

The occupational analysis shows that the proportion of male and female managers and professionals is higher among urban migrants than other migration streams. Under the management position, most of the male and female migrant workers are senior officials or administrative managers. The classification of professional urban-urban migrants shows that most of the male migrants are religious professionals and secondary school teachers. However, female migrants are primary and secondary school teachers.

For the year 2017-18, the gender wage gap among rural-urban migrants was $45 \%$, while female migrants worked $27 \%$ fewer than their male counterparts. The dynamics of the gender wage gap shows persistence in the gender wage gap among urban-urban migrants. According to the various issues of the LFS, female migrants, on average, earned $32 \%$ 
lower than their male counterparts. The recent wage gap was the highest in 2017-18 (45\%), while the smallest gap was noticed in the year 2002-03. One of the important reasons for this wage gap is the difference in the working hours of male and female workers. On average, females had $28 \%$ fewer working hours than male migrants.

\section{Conclusions}

According to the Human Development Report (HDR 2019), the Human Development Index (HDI) value (0.56) and ranking (152) of Pakistan was much lower in the South Asian Region. There were higher differences in the HDI of males and females as well. The gender-segregated Gender Development Index (GDI) value of Bangladesh (0.90), and India (0.83) was better than Pakistan (0.75). The higher differences in the mean and expected years of schooling created endowment differences, largely responsible for the gender wage gap ${ }^{3}$.

The labor migration from urban to urban areas is a significant determinant of socioeconomic and demographic changes. The urban workers earn higher wages than their rural counterparts. However, gender pay gaps exist in the urban labor markets of Pakistan. The labor force participation of female migrants among urban-urban migrants is lower than other migration flows. The study endorsed the findings of previous studies that the gender wage gap is persistent in Pakistan. The human capital development of males is more than their female counterparts. Female migrant workers, on average, earn lower wages than their male counterparts. Female migrants are younger than their male counterparts that shows their lower human capital development in the urban labor markets. Two-third of the migrants are employed in the services sector that pays higher returns. A large proportion of male and female migrants are managers and professionals. Most of the male migrants are full-time workers, while most of the females are part-time workers. Male workers are diverted more towards the financial returns, while the female workers are diverted towards social responsibilities.

The proportion of urban-urban migration in the labor's migratory stream is the secondhighest after rural-urban migration. The important migration reasons for urban-urban migrants are migration with parents followed by search and found a job. The sum of the working hours of female migrants in social activities and in the labor market is more than the working hours of male workers. Females earn lower due to their fewer working hours in the labor market. Preferably, they are engaged in household responsibilities. This factor contributes significantly to the gender pay gap (Erosa, Fuster \& Restuccia, 2015). The differences in human capital investment also increase the gender earning gap. Females have lower incentives for human capital development (Mincer \& Polachek, 1974). The gender pay gap is non-uniform, along with wage distribution (Magnani \& Zhu, 2012). 


\section{Recommendations}

The participation of females in the labor markets of Pakistan is quite vulnerable. The female labor force participation is lower than their male counterparts. Moreover, the participation of females in urban areas is much lower than their participation in rural areas. A large proportion of females are employed in the informal sector. The statistics are quite not good for female migrants. Female urban-urban migrant workers earn much lower wages than their male counterparts. Female migrant workers need special attention from policymakers to reduce the gender wage gap, such as the gender-insensitive capacity building of urban migrant workers, workplace incentives for women, and enhancement of women leadership roles, to reduce gender inequalities in the urban labor market. There are now more school-going females than the past that has reduced the gender parity to its minimal. There should be increased opportunities for sectoral and occupational segregation for female migrants. Giving equal female access to economic and social resources will ensure minimum endowment differences. It infers that the increased female working hours could lead to diminishing the gender wage gap. However, it will adversely affect the household activities of female migrants.

An optimal time allocation decision for work and household activities can minimize the gender wage gap. For future research, the study suggests decomposition of the male-female earning gap of urban-urban migrants into endowment and discrimination effects at national and provincial levels. One caveat applies here that not all the unexplained part of the gender wage gap is due to discrimination (Lee, 2012). Generally, the urban-urban migration of labor does not affect urbanization but leads to labor market disparities in different sized cities. The study also suggests an in-depth analysis of the gender earning gap in urban-urban migration transition from smaller to larger urban centers and vice versa.

\section{End Notes}

1. SDG 5 (Gender Equality) and SDG10 (Reduced Inequalities) http://www.undp.org/ content/dam/undp/library/corporate/brochure/SDGs_Booklet_Web_En.pdf

2. Gender wage gap shows how much lower are the earnings of female urban-urban migrants their male counterpart Gender wage gap $=(1-\mathrm{Wf} / \mathrm{Wm}) * 100$

3. Human Development Report 2019 http://hdr.undp.org/sites/all/themes/hdr_theme/ country-notes/PAK.pdf

\section{References}

Agesa, J. \& Agesa, R. U. (1999). Gender Differences in the Incidence of Rural to Urban Migration: Evidence from Kenya. The Journal of Development Studies, vol.35:6, pp.36-58. 
Ahmed, A. M. \& Hyder, A. (2008). Sticky Floors and Occupational Segregation: Evidence from Pakistan. The Pakistan Development Review, vol.47:4, pp.837-849.

Ahmed, S. \& Maitra, P. (2010). Gender Wage Discrimination in Rural and Urban Labour Markets of Bangladesh. Oxford Development Studies, vol.38:1, pp.83-112.

Ahmed, S. \& McGillivray, M. (2015). Human Capital, Discrimination and the Gender Wage Gap in Bangladesh. World Development, vol.67, pp.506-524.

Anspal, S. (2015). Gender Wage Gap in Estonia: A Non-Parametric Decomposition. Baltic Journal of Economics, vol.15:1, pp.1-16.

Ashraf, J. \& Ashraf, B. (1993a). Estimating the Gender Wage Gap in Rawalpindi City. The Journal of Development Studies, vol.29:2, pp.365-376.

Ashraf, J. \& Ashraf, B. (1993b). An Analysis of the Male-Female Earnings Differential in Pakistan. The Pakistan Development Review, vol.32:4, pp.895-904.

Baines, D. (2005). European Labor Markets, Emigration and Internal Migration, 18501913. In Migration and the International Labor Market 1850-1939. Routledge.

Becker, G. S. (1962). Investment in Human Capital: A Theoretical Analysis. Journal of Political Economy, vol.70:5, pp.9-49.

Becker, G. S. (1985). Human Capital, Effort and the Sexual Division of Labor. Journal of Labor Economics, vol.3:1, pp.33-58.

Becker, G. S. (1993). Nobel Lecture: The Economic Way of Looking at Behavior. Journal of 1Political Economy, vol.101:3, pp.385-409.

Dale, A., Fieldhouse, E., Shaheen, N. \& Kalra, V. (2002). The Labour Market Prospects for Pakistani and Bangladeshi Women. Work, Employment and Society, vol.16:1, pp.5-25.

De Haas, H. (2010). The Internal Dynamics of Migration Processes: A Theoretical Inquiry. Journal of Ethnic and Migration Studies, vol.36:10, pp.1587-1617.

Deaton, A. (1997). The Analysis of Household Surveys: A Micro-econometric Approach to Development Policy. The World Bank. 
Deshingkar, P. \& Grimm, S. (2004). Voluntary Internal Migration: An Update. London: Overseas Development Institute, vol.44, p.4. http://citeseerx.ist.psu.edu/viewdoc/ download?doi=10.1.1.112.6676\&rep=rep1\&type=pdf

Erosa, A., Fuster, L. \& Restuccia, D. (2016). A Quantitative Theory of the Gender Gap in Wages. European Economic Review, vol.85, pp.165-187.

Hnatkovska, V. \& Lahiri, A. (2015). Rural and Urban Migrants in India: 1983-2008. The World Bank Economic Review, vol.29:1, pp.257-270.

Haughton, J. \& Sun, W. (2018). Discrimination against Migrants in Urban Vietnam. International Advances in Economic Research, vol.24:3, pp.211-232.

ISCO (2008). International Standard Classification of Occupations Structure, Group Definitions and Correspondence Tables. Volume I, International Labour Office, Geneva. https://www.ilo.org/wcmsp5/groups/public/@dgreports/@dcomm/ @ publ/documents/publication/wcms_172572.pdf

ISIC (2008). International Standard Industrial Classification of All Economic Activities, Statistical Papers, Series M No. 4/Rev.4, Department of Economic and Social Affairs Statistics Division, United Nations New York, 2008. https://unstats.un.org/unsd/publication/seriesM/seriesm_4rev4e.pdf

Lee, L. (2012). Decomposing wage differentials between migrant workers and urban workers in urban China's labor markets. China Economic Review, 23(2), 461-470. https://doi.org/10.1016/j.chieco.2012.03.004

LFS (2017-18). Labour Force Survey, Pakistan Bureau of Statistics, Ministry of Planning, Development \& Reform, Islamabad, Pakistan, Various Issues. http://www.pbs.gov.pk/content/lfs-2010-2018-microdata

Lim, D. S., Morse, E. A., Mitchell, R. K. \& Seawright, K. K. (2010). Institutional Environment and Entrepreneurial Cognitions: A Comparative Business Systems Perspective. Entrepreneurship Theory and Practice, vol.34:3, pp.491-516.

Lucas, R. E. (2016). Internal Migration in Developing Economies: An Overview of Recent Evidence. Geopolitics, History, and International Relations, vol.8:2, pp.159-191.

Ma, X. (2018). Labor Market Segmentation by Industry Sectors and Wage Gaps between Migrants and Local Urban Residents in Urban China. China Economic Review, vol.47, pp.96-115. 
Magnani, E. \& Zhu, R. (2012). Gender Wage Differentials among Rural-Urban Migrants in China. Regional Science and Urban Economics, vol.42:5, pp.779-793.

Mincer, J. \& Polachek, S. (1974). Family Investments in Human Capital: Earnings of Women. Journal of Political Economy, vol.82:2, pp.76-108.

Mitchell, R. K., Smith, B., Seawright, K. W. \& Morse, E. A. (2000). Cross-Cultural Cognitions and the Venture Creation Decision. Academy of Management Journal, vol.43:5, pp.974-993.

Peek, P. \& Antolinez, P. (1977). Migration and the Urban Labour Market: The Case of San Salvador. World Development, vol.5:4, pp.291-302.

Pérez-Campuzano, E., Castillo Ramírez, G. \& Galindo Pérez, M. C. (2018). Internal Migration in Mexico: Consolidation of Urban-Urban Mobility, 20002015. Growth and Change, vol.49:1, pp.223-240.

PSCO (2015). Pakistan Standard Classification of occupations. Pakistan Bureau of Statistics, Government of Pakistan. http://www.pbs.gov.pk/sites/default/ files//pslm/publications/pslm_microdata_2010_11_HIES/occupation\%20code.pdf

PSIC (2010). Pakistan Standard Industrial Classification (All Economic Activities) PSIC Rev. 4, Government of Pakistan. Statistics Division, Federal Bureau of Statistics http://www.pbs.gov.pk/sites/default/files/other/PSIC_2010.pdf

Sabir, M. \& Aftab, Z. (2007). Dynamism in the Gender Wage Gap: Evidence from Pakistan. The Pakistan Development Review, vol.46:4, pp.865-882. https://www.pide.org.pk/pdf/PDR/2007/Volume4/865-882.pdf

Schultz, T. W. (1961). Investment in Human Capital. The American Economic Review, vol.51:1, pp.1-17. https://www.jstor.org/stable/pdf/1818907.pdf

Siddiqui, R. \& Siddiqui, R. (1998). A Decomposition of Male-Female Earnings Differentials. The Pakistan Development Review, vol.37:4, pp.885-898. https://www.pide.org.pk/pdf/PDR/1998/Volume4/885-898.pdf

Skeldon, R. (2009). Migration and Migration Policy in Asia: A Synthesis of Selected Cases. Migration, Development and Pro-poor Policy Choices. Asia, Regional Conference on Refugee and Migratory Movements Research Unit/DFID, Dhaka, Bangladesh, 2003. 
Van der Meer, P. H. (2008). Is the Gender Wage Gap Declining in the Netherlands?. Applied Economics, vol.40:2, pp.149-160.

WDI (2019). World Development Indicators Data Bank, The World Bank, 2019. Retrieved from https://databank.worldbank.org/data/source/world-developmentindicators

Zhang, X. N., Wang, W. W., Harris, R. \& Leckie, G. (2020). Analysing Inter-Provincial Urban Migration Flows in China: A New Multilevel Gravity Model Approach. Migration Studies, vol.8:1, pp.19-42.

Zhu, R. (2016). Wage Differentials between Urban Residents and Rural Migrants in Urban China during 2002-2007: A distributional analysis. China Economic Review, 37, 2-14.https://doi.org/10.1016/j.chieco.2015.04.002

Muhammad Umair is Lecturer in the Department of Economics, University of Karachi, Karachi, Pakistan.

Dr. Lubna Naz is an Assistant Professor in the Department of Economics, University of Karachi, Karachi, Pakistan. 